\title{
ANALISIS EFEKTIFITAS ANGGARAN BELANJA PADA DIREÇÃO NACIONAL DE APROVISIONAMENTO, LOGÍSTICA E MATERIAIS DI MINISTÉRIO DO COMÉRCIO, INDÚSTRIA E AMBIENTE TIMOR LESTE
}

\author{
Miguel de Carvalho Soares \\ Luh Putu Wiagustini \\ Fakultas Ekonomi dan Bisnis Universitas Udayana (Unud), Bali, Indonesia \\ Email: migi_b2003@yahoo.com / Telp : +670 77420764
}

\begin{abstract}
Budget Effectiveness Analysis at Direção Nacional De Aprovisionamento, Logística E Materiais In Ministério Do Comércio, Indústria E Ambiente Timor Leste. The purpose of this research is to find the effectiveness of budget expenditure in Timor Leste Direção Nacional de Aprovisionamento, Logística dan Materiais di Ministério do Comércio, Indústria e Ambiente. The level and the criteria for the effectiveness of implementation budget expenditure in Timor Leste Direção Nacional de Aprovisionamento, Logística dan Materiais di Ministério do Comércio, Indústria e Ambiente 2010-2014 very varied. Effectiveness of the highest levels in 2013 there for $100 \%$ and the lowest is on 2010 was $81 \%$. The implementation of the budget for 2012 and 2013 said effective results achieved up $90 \%$ of the analysis. However, in 2010, in 2011, the 2014 this effective still not enough because of the budget expenditure, though much the budget expenditure is still below 50 percent. The difference this happens because there are some activities that has been budget not carried out the fullest extent. Has been budgeted for other activities that program has been effective. Timor Leste Direção Nacional de Aprovisionamento, Logística dan Materiais di Ministério do Comércio, Indústria e Ambiente. The Observation activity program already has been the realization; and in accordance with planning program,
\end{abstract}

Keywords: effectiveness , Budget Expenditure, Implementation Budget

\begin{abstract}
Abstrak: Analisis Efektifitas Anggaran Belanja Pada Direção Nacional De Aprovisionamento, Logística E Materiais Di Ministério Do Comércio, Indústria E Ambiente Timor Leste. Tujuan penelitian ini menganalisis efektifitas pelaksanaan anggaran belanja pada Direção Nacional de Aprovisionamento, Logística dan Materiais di Ministério do Comércio, Indústria e Ambiente Timor Leste. Tingkat dan kriteria efektifitas pelakasanaan anggaran belanja pada Direção Nacional de Aprovisionamento, Logística dan Materiais di Ministério do Comércio, Indústria e Ambiente Timor Leste tahun 2010 - 2014 sangat bervariasi. Tingkat efektifitas tertinggi terjadi pada tahun 2013 sebesar $100 \%$ dan yang terendah terjadi pada 2010 sebesar 81\%. Pelaksanaan anggaran belanja tahun 2012 dan 2013 dikatakan efektif karena hasil analisis mencapai diatas 90\%. Akan tetapi pada tahun 2010, 2011, 2014 tingkat efektifitasnya masih kurang karena realisasi anggaran belanja memiliki perbedaan yang jauh dengan target anggaran belanja yaitu masih dibawah 90\%. Perbedaan ini terjadi karena ada beberapa program kegiatan yang dianggarankan tidak dilaksanakan semaksimal. Untuk kegiatan lain yang telah dianggarkan pelaksanaanya sudah efektif. Direção Nacional de Aprovisionamento, Logística dan Materiais di Ministério do Comércio, Indústria e Ambiente Timor Leste mengobservasi program kegiatan sudah terealiasasi dan sesuai dengan program perencanaannya.
\end{abstract}

Kata Kunci: Efektifitas, anggaran belanja, Implementasi Anggaran 


\section{PENDAHULUAN}

\section{Latar Belakang Masalah}

Setelah hampir 15 tahun merdeka, saat ini Republik Demokratik Timor Leste sedang dalam proses membangun infra estruktur. Hal tersebut dilakukan untuk mengejar ketertinggalan pembangunan dengan Negara-negara lain di Asia sehingga masalah pembangunan harus mendapatkan perhatian serius dari pemerintah. Proses pembangunan infraestruktur ini hendaknya untuk mencapai tujuan yang dituangkan dalan Rencana Strategis Nasional Republik Demokratik Timor Leste (RDTL).

Pencapaian tujuan pemerintah Republik Demokratik Timor Leste (RDTL) ini memerlukan suatu pengendalian, dimana pengendalian ini merupakan suatu proses terdiri atas tatanan organisasi pemerintah, wewenang dan tanggung jawab serta informasi untuk memungkinkan pelaksanaan pengendalian dan untuk memproses sekumpulan tindakan yang memastikan bahwa organisasi pemerintah itu bekerja mencapai tujuan.

Salah satu elemen penting dalam pencapai tujuan tersebut yaitu anggaran. Anggaran adalah perencanaan keuangan untuk masa depan. Perencanaan dan pengendalian merupakan dua persoalan yang tak dipisahkan. Perencanaan melihat ke masa depan (Future) yaitu menentukan tindakan-tindakan apa yang harus dilakukan untuk merealisasikan tujuan tertentu. Pengendalian melihat ke belakang (past), yaitu menilai apa yang telah dihasilkan dan membandingkannya dengan rencana yang telah disusun.

Pelaksanaan program pemerintah Republik Demokratik Timor Leste memerlukan adanya anggaran atau budget. Anggaran yang dimaksudkan adalah anggaran yang dialokasikan dari Anggaran Pendapatan Belanja Negara (APBN) di sahkan oleh Parlement Nasional Timor Leste. Anggaran tahunan yang dialokasikan oleh pemerintah RDTL pada tiap-tiap Kementrian di Timor Leste berdasarkan ketentuanketentuan Pemerintah yang disusun dan ditetapkan jangka waktu 5 tahun. Anggaran yang dialokasikan itu disesuaikan dengan rencana program tahunan yaitu rencana program jangka pendek, rencana program jangka menengah dan rencana program jangka panjang. Rencana anggaran tahunan ini disusun dan dilaksanakan sesuai tujuan serta target yang dicapai. Dalam peraturan pemerintah ( Decreto Lei ) Nomor 01/2013 de 23 de Janeiro: mengatakan bahwa diberikan wewenang dan tanggunjawab menjalankan dan mengimplementasikan anggaran yang ada. Undang-undang ini memiliki makna substansial yang sangat pokok yaitu pemberian wewenang dan pembiayaan yang selama ini merupakan hal yang sangat penting dan merupakan tugas dan tanggung jawab setiap kementrian. Salah satu tugas dan tanggung jawab yang diberikan tersebut adalah dalam mengelola pembangunan dan keuangan atau anggarannya masing-masing.

Berdasarkan pada komitmen Pemerintah dalam menyediakan layanan publik, melaluipengeluaranbelanjapemerintah di bidang pembangunan. Pelayanan publik yang maksimal seharusnya menjadi tujuan dari dana yang dibelanjakan oleh pemerintah. Dana yang dibelanjakan untuk mencapai sasaran pembangunan menjadi permasalahan yang sangat penting dalam alokasi pengeluaran pemerintah. Pengeluaran belanja perlu dilihat kesesuaian pelaksanaannya dengan kaidahkaidah pengelolaan anggaran secara efektifitas. Terjadinya kenaikan anggaran pendapatan dan Belanja Negara (APBN) pada Ministério do Comercio, Indústria e Ambiente, berdasarkan pada tingkat efektifitas terhadap pengelolaan anggaran belanja dengan adanya peningkatan anggaran pembangunan.

Realisasi anggaran yang dialokasikan dari anggaran APBN hendaknya berorientasi pada kepentingan umum dan memenuhi asas tertib, transparansi, akuntabilitas, konsistensi, komparabilitas, akurat dapat dipercaya dan mudah dimengerti. Sesuai dengan tahapanya maka disusun kebijakan umum APBN prioritas dan plafon anggaran sementara yang sifatnya menjadi pedoman bagi kerangka negara dalam menyusun usulan program. Kegiatan dan anggaran yang disusun berdasarkan prinsip-prinsip anggaran prestasi 
kerja yang dituangkan dalam Rencana Kerja Anggaran (RKA) dengan mempertimbangkan kondisi ekonomi dan keuangan Negara. Pembangunan ekonomi di Negara Timor Leste masih dihadapkan pada beberapa tantangan yaitu realisasi anggaran mencapai efektifitas namun outcome-nya tidak seperti apa yang diharapkan. Tantangan tersebut perlu disikapi secara bijaksana dan komprehensif dengan melakukan langkah-langkah yang lebih nyata dan terarah sehingga realisasi anggaran mencapai target (efektif) dan outcome-nya juga efektif.

Berdasarkan wewenang dan tanggun jawab demikian maka setiap kementrian semakin dituntut untuk mewujudkan akuntabilitas dan transparansi publik yang merupakan bentuk pertanggungjawaban kementrian kepada Parlement Nasional. Salah satu wujud pertanggungjawaban dan transparansi dalam pengelolaan pembangunan dan keuangan adalah diwajibkan setiap Direção untuk mempertanggungjawabkan pelaksanaan anggaran dan realisasinya pada setiap akhir tahun anggaran. Setiap Direção mempunyai wewenang dan tanggung jawab yang berbeda sesuai dengan jenis pusat pertanggung jawaban yang di pimpinnya, yang berkaitan dengan penyusunan anggaran dalam sistem manajemen pemerintah.

Anggaran pemerintah adalah merupakan salah satu alat bantu bagi manajemen suatu Direçãountuk merencanakan langkah-langkah budgeting penting serta menentukan kebijakan kementrian dimasa depan dalam periode tertentu. Anggaran suatu kementrian merupakan salah satu aspek penting didalam merencanakan keputusan yang akan diambil oleh manajemen suatu kementrian sehingga apabila terjadi kekeliruan atau ketidaktepatan dalam merencanakan atau melaksanakan anggaran dapat berakibat buruk bagi Direção tersebut. Dalam hal ini, anggaran yang disusun harus realisasi untuk mencapai target dan outcome-nya juga efektif.

Bentuk laporan pertanggungjawaban keuangan kementrian yang disusun terdiri dari laporan perhitungan APBN yang diterima dan hasil realisasinya. Kinerja keuangan pada setiap direksi dapat diukur dengan metode analisis rasio anggaran melalui data sebuah anggaran. Rasio anggaran yang dapat menunjukkan kinerja keuangan sebuah direksi adalah rasio efektifitas anggaran yaitu dengan cara membandingkan jumlah anggaran digunakan dibandingkan dengan anggaran yang direalisasikan pada periode tertentu.

\section{Perumusan Masalah}

Berdasarkan uraian latar belakang masalah, maka dapat dirumuskan pokok permasalahan dalam penelitian ini antara lain: Bagaimanakah efektifitas alokasi dan realisasi anggaran Belanja pada Direção Nacional de Aprovisionamento, Logística e Materiais Materiais di Ministério do Comércio, Indústria e Ambiente Timor Leste periode 2010 sampai dengan 2014?

\section{Tujuan Penelitian}

Berdasarkan rumusan pokok permasalahan di atas, maka tujuan penelitian adalah sebagai berikut:

Untuk mengetahui efektifitas dari pengelolaan keuangan pemerintah pada kementrian dilihat dari pengalokasian anggaran pemerintah dalam Ministério do Comércio, Indústria e Ambiente Timor Leste dari periode 2010 sampai dengan 2014.

\section{Manfaat Penelitian}

Penelitian ini diharapkan dapat memberikan manfaat sebagai berikut:

Manfaat Teoritis, penelitian ini diharapkan dapat memberikan bukti empiris mengenai pengelolaan keuangan pada Directorat Nasional Procurement, Logistik dan Materiais DNALM-MCIA.

Manfaat Praktis, penelitian ini diharapkan kontribusi pemikiran kepada DNALM MCIA dalam rangka melakukan kebijakan-kebijakan dalam kaitan dengan pelaksanaan anggaran belanja tahunan untuk masa yang akan datang.

\section{KAJIAN PUSTAKA \\ Pengertian Anggaran}

Anggaran merupakan alat manajemen 
untuk mencapai tujuan perusahaan, sehingga anggaran dapat dirancang berdasarkan kondisi perusahaan disesuaikan dengan data tertulis mengenai seluruh kegiatan organisasi perusahaan yang dinyatakan dalam bentuk kuantitatif ( satuan uang ) untuk jangka waktu tertentu.

Anggaran digunakan untuk mengarahkan suatu kegiatan dan juga sebagai alat perbandingan dalam mengukur hasil pelaksanaan kegiatan, sehingga proses pelaksanaan terkendali. Ada beberapa pengertian yang diberikan mengenai anggaran oleh beberapa kalangan ahli. Tetapi pengertian tersebut pada dasarnya memiliki maksud yang sama. Freeman ( 2003 ) mengungkapkan anggaran adalah sebuah proses yang dilakukan oleh organisasi sektor publik untuk mengalokasikan sumber daya yang dimilikinya kepada kebutuhan-kebutuhan yang tidak terbatas (the process of allocating resources to unlimited demands).

Menurut Mulyadi ( 2006:488) pengertian anggaran bahwa : anggaran merupakan suatu rencana kerja yang dinyatakan secara kuantitatif, yang diukur dalam suatu moneter standard dan satuan ukuran lain, yang mencakup jangka waktu satu tahun, sedangkankan Eduard et all yang diterjemahkan oleh Sustry Ambarriani ( 2005:350), mengemukakan pengertian anggaran yaitu: "Anggaran adalah rencaran kuantitatif terhadap operasi organisasi, anggaran mengidentifikasikan sumber daya dan komitmen yang dibutuhkan untuk memenuhi tujuan organisasi selama periode anggaran. Anggaran meliputi aspek keuangan maupun non keuangan dari operasi yang direncanakan. Anggaran pada suatu periode anggaran dan merupakan proyeksi dari hasil operasi”.

Munandar (2006:01) mengemukakan pengertian anggaran yaitu: "anggaran adalah suatu rencana yang disusun secara sistematis yang meliputi seluruh kegiatan perusahaan dinyatakan dalam unit (kesatuan) moneter dan berlaku untuk jangka waktu ( periode ) tertentu yang akan datang". Selanjutnya Henry Simamora ( 2007: 202 ) pengertian anggaran adalah sebagai berikut: "anggaran mengidentifikasi sumber daya dan komitmen yang dibutuhkan untuk memenuhi kebutuhan tujuan organisasi selama periode dianggarkan". Anggaran dapat diartikan sebagai pernyataan mengenai estimasi kinerja yang hendak dicapai selama periode waktu tertentu dalam ukuran financial. Anggaran juga merupakan rencana finansial yang menyatakan : rencana organisasi untuk melayani masyarakat atau aktivitas lain yang dapat mengembangkan kapasitas organisasi dalam pelayanan; Estimasi besarnya biaya yang harus dikeluarkan dalam merealisasikan rencana tersebut; Perkiraan sumber mana saja yang akan menghasilkan pemasukan serta seberapa besar pemasukan tersebut.

Berdasarkan uraian di atas maka dapat ditarik kesimpulan bahwa anggaran merupakan suatu rencana yang disusun secara sistematis yang meliputi seluruh kegiatan perusahaan yang dinyatakan dalam unit ( kesatuan ) moneter dan berlaku untuk jangka waktu ( periode )tertentu yang akan datang, maka tampak bahwa sedikitnya anggaran mempunyai empat unsur yaitu:

1) Rencana ialah suatu penentuan terlebih dahulu tentang aktivitas atau kegiatan perusahaan yang akan dilakukan diwaktu yang akan datang.

2) Meliputi seluruh kegiatan perusahaan, yaitu mencakup semua kegiatan yang akan dilakukan oleh semua bagian-bagian yang ada dalam perusahaan.

3) Dinyatakan dalam unit moneter, yaitu unit ( kesatuan ) yang dapat diterapkan pada berbagai kegiatan perusahaan.

4) Jangka waktu tertentu yang akan datang yaitu yang menunjukkan bahwa anggaran berlaku hanya untuk masa yang akan datang.

\section{Dasar Hukum Keuangan dalam Konstitusi}

Anggaran dengan prosedur-prosedur yang berkaitan dengannya diatur oleh beberapa ketentuan-ketentuan dalam undanga-undang dasar Timor Leste. Ketentuan-ketentuan konstitusi RDTL pasal 145 (Tentang Anggaran) 
1) Anggaran Negara disusun oleh pemerintah dan disetujui oleh Parlemen Nasional.

2) Undang-undang anggaran mengatur dan berdasrakan efektifitas, suatu uraian pendapatan dan pembelanjaan Negara, serta menghindarkan adanya peruntukan dan dana rahasia. Pelaksanaan anggaran dipantau oleh pengadilan tinggi administrasi, pajak dan pemeriksaaan keuangan serta oleh Parlement Nasional.

Konstitusi RDTL pasal 115 ayat $1(\mathrm{~d})$ mengatakan bahwa pemerintah memiliki kewenangan untuk menyusun rencana dan anggaran negara serta menjalankannya dengan persetujuan parlemen nasional. Pasal 96 mengatakan bahwa:

1) Parlemen Nasional memiliki kewenangan tunggal untuk membuat undangundang mengenai: a) kebijakan perpajakan, b) system anggaran.

2) Parlemen juga memiliki kewenangan untuk: a) memusyawarahkan rencana dan anggaran Negara serta dalam laporan pelaksanaannya, b) memantau pelaksanaan anggaran Negara.

\section{Perumusan Anggaran \\ Belanja Negara Timor Leste}

Pendapatan

Anggaran Pendapatan dan Belanja Negara (APBN) diajukan oleh perdana Menteri dalam bentuk rancangan Undang Undang kepada Parlamen (Dewan Perwakilan Rakyat). Setelah melalui pembahasan, Parlamen (Dewan Perwakilan Rakyat) menetapkan Undang Undang tentang Anggaran Pendapatan dan Belanja Negara (APBN) selambat lambatnya 2 bulan sebelum tahun anggaran dilaksanakan.

Berdasarkan perkembanganya jika ditengah tengah tahun anggaran yang berjalan, Anggaran Pendapatan dan Belanja Negara (APBN) dapat mengalami perubahan. Pada kondisi tersebut Pemerintah harus mengajukan kembali rancangan Undang Undang Perubahan Anggaran Pendapatan dan Belanja Negara (RAPBN) untuk mendapatkan persetujuan Dewan Perwakilan Rakyat (DPR) kembali. Perubahan akan dilakukan paling lambat akhir
Trimester ke III yaitu di awal bulan Oktober tahun berjalan, setelah pembahan dengan badan Anggaran Parlamen (DPR).

Anggaran Pendapatan dan Belanja Negara (APBN) dibebankan menjadi 5 bagian yaitu :

1) Salario e Vencimento ( Gaji dan Tunjangan)

2) Bens e Serviços (Anggaran Rutin )

3) Transferencia

4) Capital Menor ( Anggaran Belanja Modal)

5) Capital Desenvolvimento (Anggaran Pembangunan).

\section{Fungsi Anggaran}

Anggaran Pendapatan dan Belanja Negara (APBN) memiliki 6 fungsi dalam rangka membentuk struktur perekonomian Negara antara lain :

1) Fungsi Otoritas

Bahwa Naggaran Pendapatamn dan

Belanja Negaran (APBN) menjadi dasar

untuk melaksanakan pendapatan dan Belanja Negara tahun yang bersangkutan,

dengan demikian pembelanjaan atau pendapatan dapat dipertanggungjawabkan

kepada Rakyat.

2) Fungsi Perencanaan

Bahwa Anggaran Pendapatan dan Belanja Negara (APBN) dapat menjadi pedoman bagi Negara untuk merencanakan kegiatan pada tahun tersebut. Bila pembelanjaan telah direncanakan sebelumnya, maka Negara dapat membuat rencana rencana untuk mendukung pembelanjaan tersebut. Misalnya telah dianggarkan membangun Proyek Pembanguna jalan, maka Pemerintah dapat mengambil tindakan untuk persiapan proyek tersebut agar bisa berjalan dengan lancar

3) Fungsi Pengawasan

Anggaran Pendapatan dan Belanja Negara (APBN) harus menjadi pedoman untuk menilai apakah kegiatan penyelenggaraan Pemerintah Negara telah sesuai dengan jetentuan yang telah ditetapkan.

4) Fungsi Alokasi

Bahwa suatu Anggaran Pendapatan 
dan Belanja Negara (APBN) harus diarahkan untuk mengurangi pengangguran dan pemborosan sumber daya serta meningkatkan efektifitas perekonomian.

5) Fungsi Distribusi

Bahwa kebijakan Anggaran

Pendapatan dan Belanja Negara (APBN) harus memperhatikan rasa keadilan.

6) Fungsi Stabilitas.

Bahwa Anggaran Pendapatan dan Belanja Negara (APBN) menjadi alat untuk memelihara dan mengupayakan keseimbangan fundamental perekonomian.

\section{Pengeluaran Anggaran Negara}

Pengeluaran Negara diartikan sebagai pengeluaran Pemerintah yang seluas luasnya, dalam rangka memenuhi kebutuhan penyelenggaraan Negara tergantung pada macam dan sifat dari pengeluaran Pemerintah tersebut baik untuk kebutuhan harian atau rutin untuk memenuhi pencapain pembangunan. Pengeluaran Pemerintah dapat dibedakan menjadi (Soetrisno, 1982 : 339).

a) Pengeluaran rutin (Belanja rutin)

b) Pengeluaran untuk Pembangunan

\section{Pengeluaran Rutin}

Pengeluaran rutin merupakan pengeluaran yang digunakan untuk pemeliharaan dan penyelenggaraan pemerintah yang meliputi belanja pegawai, belanja barang, dan pengeluaran rutin lainnya. Pengeluaran rutin digunakan untuk menjaga kelancaran penyelenggaraan pemerintah, kegiatan operasional dan pemeliharaan asset negara, pemenuhan kewajiban kepada luar negeri, perlindungan kepada masyarakat miskin dan kurang mampu serta menjaga stabilitas perekonomian.

\section{Pengertian Kinerja}

Menurut Lembaga Administrasi Negara: (Inpes nomor 7 tahun 1999 tentang akuntabilitas kinerja instansi pemerintah) mengatakan bahwa kinerja adalah gambaran mengenai tingkat pencapaian pelaksanakan suatu kegiatan / program / kebijaksanaan dalam mewujudkan sasaran, tujuan, Misi dan visi organisasi. Kinerja (Performance) adalah hasil kerja yang dapat dicapai seseorang atau kelompok orang dalam suatu organisasi, sesuai dengan wewenang dan tanggung jawab masing-masing dalam rangka upaya mencapai tujuan organisasi yang bersangkutan, tidak melanggar hukum dan sesuai dengan modal dan etika ( prawirosentono, 1999:2)

Kinerja adalah gambaran mengenai tingkat pencapaian pelaksanaan suatu kegiatan / program / kebijaksanaan dalam mewujudkan sasaran, tujuan dan misi dan visi organisasi yang tertuang dalam perumusan skema strategis (strategic planning ) suatu organisasi. Secara umum dapat juga dikatakan bahwa kinerja merupakan prestasi yang dapat dicapai oleh organisasi dalam periode tertentu (Bastian, 2001 : 329)

\section{Penilaian Kinerja}

Penilaian kinerja merupakan suatu kegiatan yang sangat penting karena dapat digunakan sebagai ukuran keberhasilan suatu organisasi dalam mencapai misinya. Untuk organisasi pelayanan publik, informasi mengenai kinerja sangat berguna untuk menilai seberapa jauh pelayanan yang diberikan oleh organisasi itu memenuhi harapan. Penilaian kinerja tidak cukup hanya dilakukan dengan menggunakan indikatorindikator yang melekat seperti efektitifas, tetapi harus dilihat juga dari indicator lainnya seperti : kepuasan pengguna jasa, akuntabilitas dan responsitivitas. Dengan melakukan penilaian terhadap kinerja maka upaya untuk memperbaiki kinerja bisa dilakukan secara lebih terarah dan sistematis. Kesulitan lain dalam menilai kinerja birokrasi public muncul karena tujuan dan misi birokrasi publik seringkali bukan hanya sangat kabur, tetapi juga bersifat multidimensional (Dwiyanto, 2002 : 44-46).

Pengukuran kinerja digunakan untuk penilaian atas keberhasilan / kegagalan pelaksanaan kegiatan/program/kebijaksanaan sesuai dengan sasaran dan tujuan yang telah ditetapkan dalam rangka mewujudkan misi dan visi instansi pemerintah (LAN, 1999 : 17). Pengukuran kinerja harus mampu 
memahami hasil-hasil dari suatu aktifitas program dibanding dengan tujuan awalnya, agar dapat menghasilkan pengukuran yang baik dibutuhkan artikulasi yang jelas tentang rencana strategis setiap Departemen / LPND yang mencakup visi, misi, tujuan dan sasran yang dapat diukur serta berhubungan dengn hasil dari kegiatan. Selanjutnya pengukuran kinerja harus mengukur hasil, akibat atau output dari pengeluaran anggaran yang dipercaya kepada instansi yang bersangkutan.

Pengukuran kinerja juga merupakan alat yang dapat digunakan oleh menajemen untuk:

1) Meningkatkan kualitas pemgambilan keputusan dan akuntabilitasnya.

2) Menilai pertanggungjawaban pencapaian tujuan dan sasaran oleh manajemen atas program-program.

3) Mengelola program secara efisien

4) Menyediakan data dalam rangka pelaksanaan fungsi pengendalian program

5) Membuat kebijaksanaan anggaran

6) Mengelola dan mengukur hasil program

7) Umpan balik bagi manejemen dalam rangka meningkatkan kinerjanya di masa yang akan datang.

8) Mempertanggungjwabkan sumber daya telah dipercayakan kepada manajemen. ( LAN, 1999: 3-4)

Keberhasilan ataupun kegagalan manajemen dapat diukur dengan melakukan:

1) Perbandingan antara kinerja nyata dengan kinerja yang direncanakan;

2) Perbandingan antara kinerja nyata dengan hasil ( sasaran ) yang diharapkan;

3) Perbandingan antara kinerja nyata tahun ini dengan tahun-tahun sebelumnya;

4) Perbandingan kinerja suatu instansi dengan instansi lain yang unggul dibidangnya ( benchmarking /patok duga);

5) Perbandingan capaian tahun berjalan dengan rencana dalam lima tahun (tren mencapainya).

\section{Indikator Penilaian Kinerja}

Menurut Dwiyanto (2002 : 50-51) terdapat beberapa indikator yang biasanya digunakan untuk mengukur kinerja organisasi pelayanan publik sebagai berikut:

1) Efektifitas, terkait dengan rasionalitas teknik, nilai, misi tujuan organisasi serta fungsi agen pembangunan.

2) Keadilan, kiteria ini erat kaitannya dengan konsep ketercukupan atau kepantasan.

3) Daya tanggap, organisasi pelayanan publik merupakan bagian dari daya tanggap Negara atau pemerintah akan kebutuhan vital masyarakat.

Indikator kinerja adalah ukuran kuantitatif dan kualitatif yang menggambarkan tingkat pencapaian suatu sasaran atau tujuan yang telah ditetapkan dengan memperhitungkan indikator masukkan ( inputs), keluaran ( output), hasil (outcomes), manfaat ( benefits), dan dampak ( impacts), (LAN, 1999;7).

a) Indikator masukan ( inputs) adalah segala sesuatu yang dibutuhkan agar pelaksanaan kegiatan dapat berjalan untuk menghasilkan keluaran. Indikator ini dapat berupa dana, sumber daya manusia, informasi, kebijaksanaan dan peraturan perundangundangan dan sebagainya.

b) Indikator keluaran adalah sesuatu yang diharapkan langsung dicapai dari suatu kegiatan yang dapat berupa fisik dan atau non fisik.

c) Indikator hasil adalah segala sesuatu yang mencerminkan berfungsinya keluaran kegiatan pada jangka menengah ( efek langsung).

d) Indikator manfaat adalah sesuatu yang terkait dengan tujuan akhir dari pelaksanaan kegiatan.

Indikator dampak adalah pengaruh yang ditimbulkan baik positif maupun negatif pada setiap tingkatan indikator berdasarkan asumsi yang telah ditetapkan.

\section{Pengertian realisasi anggaran}

Pengeretian realisasi menurut kamus besar bahasa Indonesia (KBBI) (2006) adalah: Realisasi adalah menjadi nyata, perwujudan menjadi nyara (Mengusahakan melaksanakan menjadi nyata)".

Menurut Permendagri

$(2007: 4)$ 
realisasi anggaran adalah:

"Suatu rencana yang disusun secara sistematis yang meliputi seluruh kegiatan perusahaan dan berlaku untuk jangka waktu tertentu dan diwujudkan menjadi nyata, agar rencana yang telah disusun oleh perusahaan dapat tercapai”.

Dari definisi diatas dapat disimpulkan bahwa antara pengalokasi anggaran dan realisasi anggaran adalah urutan dalam membuat laporan dari pelaksanaan realisasi yang digunakan untuk menjalankan kegiatan pemerintah yang dinyatakan dalam unit (satuan) moneter dalam selama periode tertentu.

\section{Penyusunan laporan anggaran}

Pelaporan keuangan pemerintah harus menyajikan secara wajar dan mengungkapkan secara penuh atas kegiatan pemerintah dan sumber daya ekonomis yang dipercayakan, serta menunjukkan ketaatan terhadap peraturan perundang-undangan. Fungsi laporan keuangan adalah untuk mengkomunikasikan informasi keuangan kepada para pemakai. Standar umum pelaporan keuangan untuk memenuhi fungsi tersebut.

Laporan keuangan harus disajikan dengan memenuhi hal berikut ini:

a. Disajikan dengan menunjukkan perbandingan antara periode berjalan dengan periode sebelumnya. Agar perbandingan dapat bermanfaat, maka informasi keuangan dari periode berjalan harus dilaporkan secara konsisten dengan informasi pada periode sebelumnya. Apabila terjadi perubahan akuntansi harus diungkapkan dalam laporan keuangan.

b. Diterbitkan tepat waktu segera setelah periode akuntansi berakhir.

c. Laporan keuangan harus menyajikan transaksi-transaksi atau kejadian-kejadian yang penting. Informasi laporan keuangan dapat diandalkan bila pemakai laporan dapat menggunakan informasi tersebut untuk pengambilan keputusan atas transaksi dan kejadian yang penting berdasarkan kondisi keuangan yang sesungguhnya.

d. Mencakup laporan perhitungan anggaran, neraca, laporan arus kas dan nota perhitungan anggaran.

\section{Efektifitas}

Efektifitas berasal dari kata "Efektif" yang berarti ada efeknya; akibat; keadaan berpengaruh, kesannya; dapat berhasil; berhasil guna. Menurut T. Hani Handoko makna efektifitas dapat di artikan sebagai kemampuan untuk memilih tujuan yang tepat atau peralatan yang tepat untuk mencapai tujuan yang di tetapkan. Efektifitas juga dapat di artikan sebagai perbedaan kata yang menunjukkan taraf tercapinya suatu tujuan, dengan kata lain bahwa suatu usaha dapat di katakan efektif jika usaha tersebut tercapai tujuannya.

Terdapat beberapa kriteria yang dapat di gunakan untuk menilai bahwa suatu tujuan tersebut berjalan secara efektif yaitu:

1) Kegunaan, agar berguna bagi manajemen dalam pelaksanaan fungsifungsinya yang lain, suatu rencana harus fleksibel, stabil, berkesinambungan dan sederhana.

2) Ketepatan dan obyektifitas, semua rencana harus di evaluasi untuk mengetahui apakah jelas, ringkas, nyata dan akurat.

3) Rung lingkup, perlu memperhatikan prinsip-prinsip kelengkapan

4) Biaya yang menyangkut waktu, usaha dan aliran emosional

5) Akuntanbilitas, yang terdiri dari tanggung jawab atas pelaksanaan dan tanggung jawab atas implementasi

6) Ketepatan waktu dengan membuat perencanaan di sesuaikan dengan perubahan yang sedang terjadi.

Efektifitas dalam suatu organisasi biasanya di pusatkan pada evaluasi hasil kerja pimpinan.Teori Efektifitas menurut Makmur, Syarif Pemberdayaan Sumber Daya manusia dan Efektifitas organisasi. PT raja Grafindo Persada, Jakarta, (2008 hal.124) dan Steers M, Richard, Efektifitas Organisasi, Erlangga, Jakarta, (1985, hal.2), setiap bentukan sebuah organisasi pasti memiliki sebuah tujuan, dalam hal pencapaian tujuan tentu ada yang tercapai, lambat, cepat atau malah tidak 
mencapain tujuan yang diharapakan, oleh sebab itu penilaian atas usaha pencapaian tujuan merupakan penilaian efektifitas. Seperti halnya teori efektifitas secara umum, para ahli pun memiliki beragam pandangan terkait dengan konsep efektifitas organisasi.

Beberapa teori mengenai Efektifitas, adalah sebagai berikut:

1) Ndraha menyatakan bahwa "Efektifitas organisasi adalah tingkat pencapain tujuan organisasi (target) atau dengan rumus:

$$
\mathrm{E}=\mathrm{R} / \mathrm{T}
$$

Keterangan : E: Efektifitas

$$
\text { R: Realisasi }
$$

T: Target.

$\mathrm{R}$ adalah proses dalam hal ini proses produksi, dan setiap proses terdiri dari input, throughput dan output.

Berdasarkan rumusan di atas, penilaian efektifitas dengan melihat hubungan antara tujuan yang di program dengan hasil yang telah di capai. Hasil tidak semata-mata di nilai dari out put saja, tetapi di dalamnya terdapat input dan proses. Umumnya teori efektifitas organisasi masih mengutamakan out put saja sebagai penilaian efektifitas, terkadang input dan proses sering di abaikan.

2) Steers misalnya: "makin rasional suatu organisasi, makin besar upayanya pada kegiatan yang mengarah ke tujuan. Makin besar kemajuan yang diperoleh kearah tujuan, organisasi makin efektif pula. Efektifitas di pandang sebagai tujuan akhir organisasi" (Steers, 1977:2). Pernyataan Steers lebih melihat efektifitas merupakan tujuan akhir sebuah organisasi. Steers menambahkan, bahwa cara yang terbaik untuk meneliti efektifitas ialah memperlihatkan secara serempak tiga buah konsep yang saling berhubungan:

a) Faham mengenai optimasi tujuan

b) Perspektif sistimatika, dan

c) Tekanan pada segi perilaku manusia dalam susunan organisasi.

Ketiga hal ini adalah satu kesatuan yang membangun efektifitas. Agar dapat di ukur target harus di deduksi atau di jabarkan dari tujuan yang paling abstrak atau universal ke tujuan yang konkret. Steers berpendapat bahwa: "tujuan tidak perlakukan sebagai keadaan akhir yang statis, tetapi sebagai sesuatu yang dapat berubah dalam perjalanan waktu". Lagi pula tercapainnya tujuan-tujuan jangka pendek tertentu dapat mempersembahkan masukan-masukan (faktor-faktor produksi) baru demi penetuan tujuan berikutnya. Jadi, tujuan mengikuti suatu proses dalam organisasi bila kita memakai perspektif system."Pengertian Efektifitas" secara umum menunjukkan sampai seberapa jauh tercapainya suatu tujuan yang terlebih dahulu ditentukan.

3) Menurut Hidayat (1986), pada artikel perbankan, yang menjelaskan bahwa: "efektifitas adalah suatu ukuran yang menyatakan seberapa jauh target (kuantitas, kualitas, dan waktu) telah tercapai. Dimana makin besar presentase target yang dicapai, maka tinggi efektifitasnya”.

Efektifitas merupakan suatu ukuran yang memberikan gambaran seberapa jauh target dapat tercapai (Sedarmayanti, 1995:61). Pendapat tersebut menyatakan bahwa efektifitas merupakan suatu ukuran yang memberikan gambaran seberapa jauh target yang telah ditetapkan sebelumnya oleh lembaga atau organisasi dapat tercapai.

4) Menurut Devas (1989:279) menyatakan bahwa efektifitas adalah hasil guna kegiatan pemerintah dalam mengurus keuangan daerah haruslah sedemikian rupa, sehingga memungkinkan program dapat direncanakan dan dilaksanakan untuk mencapai tujuan penelitian biaya serendah rendahnya dan dalam waktu secepat-cepatnya. Apabila dikaitkan dengan penerimaan pendapatan maka efektifitas yang dimaksud adalah seberapa besar berhasil mencapai target penerimaan pendapatan maka efektifitas yang dimaksud adalah seberapa besar berhasil mencapai target penerimaan pendapatan yang seharusnya dicapai pada suatu periode tertentu.

5) Menurut Osborne (1997:389) menyatakan bahwa efektifitas adalah merupakan ukuran dari suatu kualitas output ketika kita mengukur efektifitas, kita akan menjadi tabu apakah investasi kita 
berguna atau tidak. Efektifitas penerimaan pendapatan merupakan perbandingan antara realisasi penerimaan pajak pengambilan dan pemanfaatan penerimaan pendapatan yang ditetapkan guna mengetahui berhasil atau tidaknya pencapaian tujuan.

6) Menurut Mardiasmo dan Mahpatih (2002:11), bahwa rasio efektifitas menggambarkan kemampuan pemerintah daerah dalam merealisasikan pendapatan daerah yang direncanakan dibandingkan dengan target yang ditetapkan berdasarkaan potensi riil daerah.

Kemampuan Negara dalam menjalankan tugasnya dikatagorikan efektif apabila rasio yang dicapai maksimal $100 \%$. Semakin tinggi rasio efektifitas menggambarkan kemampuan keuangan yang semakin baik. Sesuai dengan kriteria yang telah ditetapkan dalam penilaian berdasarkan pada keputusan peraturan pemerintah (Decreto Governo) No. 13, tahun 2009 tentang pedoman penilaian dan kinerja keuangan.

\section{Penelitian sebelumnya}

Penelitian yang berhubungan dengan efektifitas dan efisiensi pengelolaan keuangan daerah merupakan hal penting untuk diketahui.Penelitian tersebut menggunakan berbagai alat analisis rasio keuangan yang telah dikemukakan sebelumnya. Penelitian yang dilakukan oleh Ada beberapa penelitian sebelumnya.

1) Dari penelitian yang dilakukan oleh Miguel Araujo (2014) rasio efektifitas pengelolaan pendapatan dan komponen pajak daerah di kabupaten Dili. Hasil penelitian yang dilakukan oleh Miguel araujo diperoleh hasil sebagain berikut : Efisiensi Penerimaan Daerah selama delapan tahun yaitu dari tahun anggaran 2005 sampai dengan 2012 ratarata sebesar 71,48 persen. Kondisi ini berarti Pengelolaan Penerimaan Daerah Distric Dili dapat dikatakan efesien, karena realisasi Penerimaan Daerah lebih besar daripada biaya-biaya yang dikeluarkan untuk mencapai target Penerimaan Daerah tersebut Efektifitas Penerimaan Daerah Distric Dili selama delapan tahun yaitu tahun anggaran 2005 sampai dengan 2012 rata-rata diatas seratus persen, ini berarti bahwa pengelolaan pendapatan daerah Distrik Dili sangat efektif. Lebih lanjut dikatakan bahwa tingkat efektifitas Penerimanan daerah Distric Dili yang telah dicapai menunjukan bahwa kinerja pemerintah dalam merealisasikan Pendapatan Daerah yang telah direncanakan sudah baik. Hal ini disebabkan oleh perekonomian Daerah Dili dari tahun ke tahun mengalami peningkatan. Membaiknya perekonomian daerah membuat pendapatan masyarakat di Dili ikut meningkat, begitu juga dengan tingkat konsumsinya. Peningkatan ini berdampak pada penerimaan pajak daerah sebagai salah satu komponen Pendapatan Daerah yang memiliki kontribusi paling tinggi terhadap penerimaan daerah.

2) Penelitian lain yang mirip dengan penelitian ini adalah penelitian yang dilakukan oleh Sunandar (Dosen Progrom Studi Akuntansi Politeknik Harapam Bersama) yang berjudul " Analisis Efektifitas dan efisiensi pengelolaan Anggaran Pendapatan dan Belanja pada Unit Pengelolaan KeuanganBadan Keswadayaan Masyarakat (UPKBKM) Mandiri Sejahtera Kelurahan Panggung Kota Tegal ". Hasil analisis perhitungan rasio efektifitas anggaran pendapatan pada tahun 2008 dan 2010 Unit pengelolaan keuanganBadan Keswadayaan Masyarakat (UPKBKM) Mandiri Sejahtera Kelurahan Panggung Kota Tegal dinilai sangat efektif. Pada tahun 2009 perhitungan rasio efektifitas anggaran pendapatan Unit pengelolaan keuangan-Badan Keswadayaan Masyarakat (UPK-BKM) Mandiri Sejahtera Kelurahan Panggung Kota Tegal dinilai cukup efektif dalam pengelolaan anggaran pendapatan. Hasil perhitungan efisiensi anggaran pendapatan, pada tahun 2008-2010 Unit pengelola Keuangan-Badan Keswadayaan Masyarakat (UPK-BKM) Mandiri Sejahtera Kelurahan Panggung Kota Tegal dinilai tidak efisien. Hasil perhitungan efisiensi anggaran belanja, hanya pada tahun 2009 Unit pengelolaan keuangan-Badan Keswadayaan Masyarakat (UPK-BKM) Mandiri Sejahtera Kelurahan Panggung Kota Tegal dinilai efisien dalam pengelola anggaran belanja. Pada tahun 2008 dan 2010 Unit 
pengelolaan keuangan-Badan Keswadayaan Masyarakat ( UPK-BKM ) Mandiri Sejahtera Kelurahan Panggung Kota Tegal dinilai tidak efisien dalam pengelolaan anggaran belanja.

Persamaan penelitian pada penulis ini lebih terfokus pada sebuah Direção Nacional de Aprovisionamento, Logistica e Materiais di Ministério do Comércio, Indústria e Ambiente Timor Leste, DNALM-MCIA. Perbedaan pada Penelitian penulisan ini hanya terfokus pada analisis alokasi anggaran yang sudah dilakukan DNALM dengan menggunakan analisis rasio efektifitas.

\section{Kerangka Berpikir}

Berdasarkan kajian pustaka, teori dan penelititan terdahulu maka dapat dirumuskan suatu design penelitian yang akan dipergunakan sebagai acuan dalam penelitian ini yaitu kerangka berpikir dalam penelitian ini dapat disajikan dalam gambar dengan model deskriptif pada seperti skema berikut :

\section{Kerangka Konseptual}

Penelitian ini adalah penelitian deskriptif maka kerangka konseptual penelitian ini tidak bisa digambarkan namun diuraikan secara narasi. Penelitian ini tentang Efektifitas penggunaan Anggaran Belanja. Sumber dana berasal dari Anggaran Pendapatan Belanja Negara APBN Timor Leste. Setiap kementrian akan melaksanakan anggaran yang di anggarkan sesuai dengan kegiatan pada masing-masing pos line item yatiu pada pos gaji dan tunjangan, pos belanja rutin dan pos belanja modal yang sudah direncanakan pertahunnya. Selanjutnya akan dianalisis pada masing-masing pos anggaran belanja yaitu dengan cara membandingan anggaran belanja dengan realisasi sehingga dapat diketahui efektifitas penggunaan anggaran yang dikaitkan dengan outcome yang diharapkan.

\section{METODE PENELITIAN}

Rancangan dan Ruang Lingkup Penelitian

Dalam penelitian ini, yang menjadi obyek penelitian adalah laporan perhitungan anggaran pendapatan dan belanja pada
Direção Nacional Aprovisionamento, Logistica e Materiais-DNALM di Ministério do Comércio, Indústria e Ambiente, pada tahun anggaran 2010, tahun anggaran 2011, tahun anggaran 2012, tahun anggaran 2013, dan tahun anggaran 2014.

Penelitian ini merupakan jenis penelitian deskriptif kuantitatif yang menganalisis tentang efektifitas dari pengelolaan anggaran pemerintah pada Direção Nacional de Aprovisionamento, Logistica e Materiais-DNALM di Ministério do Comérci, Indústria e Ambiente.

\section{Variabel Penelitian}

Identifikasi Variabel Penelitian

Beberapa variabel pokok yang dipergunakan dalam penelitian ini adalah sebagai berikut: Tingkat efektifitas dalam merealisasi anggaran pemerintah

\section{Definisi operasional Variabel}

Definisi operasional serta penjelasan atas data yang dipergunakan dalam pengamatan ini adalah sebagai berikut:

Tingkat Efektifitas alokasi anggaran merupakan kemampuan DNALM dalam merealisasikan anggaran yang direncanakan dibandingkan dengan target yang ditetapkan pada periode-periode 2010-2014 yang diukur dengan formula sebagai berikut:

Tingkat Efektifitas = Realisasi Penerimaan Anggaran x 100\% Target Penerimaan Anggaran

Langkah-langkah untuk perhitungan rasio efektifitas adalah:

a) Membuat Tabel target anggaran dan realisasi anggaran untuk masing-masing pos belanja tahun anggaran 2010 sampai dengan tahun anggaran 2014.

b) membandingkan masing-masing pos belanja dengan total realisasi anggaran untuk masing-masing pos tahun anggaran.

\section{Jenis dan Sumber Data}

Jenis data yang dipergunakan dalam penelitian ini meliputi :

1) Data primer yaitu data yang diperoleh secara langsung dari pejabat dan staf badan pengelolaan keuangan dan aset pemerintah di 
Tabel 1

Analisis efektifitas alokasi Anggaran Tahun 2010-2014

\begin{tabular}{lrrrrr}
\hline Tahun & $\begin{array}{c}\text { Anggaran Belan- } \\
\text { ja }(\$)\end{array}$ & $\begin{array}{r}\text { Realisasi Belan- } \\
\text { ja }(\$)\end{array}$ & Selisih $(\$)$ & $\%$ & Ket \\
\hline 2010 & $1,112,880.00$ & $905,781.11$ & $207,098.89$ & 81 & Cukup Efektif \\
2011 & $1,073.000 .00$ & $877,094.24$ & $195,905.76$ & 82 & Cukup efektif \\
2012 & $485,000.00$ & $456,813.05$ & $28,186.95$ & 94 & Efektif \\
2013 & $1,093,000.00$ & $1,097,544.75$ & $-4,544.75$ & 100 & Efektif \\
2014 & $1,000,000.00$ & $884,515.71$ & $115,484.29$ & 88 & Cukup efektif \\
& & & Rata-rata & 88,94 & \\
\hline
\end{tabular}

Sumber : Direção Nacional Aprovisionamento, Logistica e Materiais di Ministério do Comércio, Indústria e Ambiente Timor Leste 2010-2014 (Data diolah )

Ministério do Comercio, Indústria e Ambiente - Timor Leste.

2) Data sekunder yang diperoleh melalui pengamatan langsung pada dokumen-dokumen yang terkait pada bagian pembukuan yang berupa Buku laporan tahunan, Buku Budget plan report, Buku perhitungan anggaran.

\section{Metode Pengumpulan Data}

Metode pengumpulan data yang dipergunakan dalam penelitian ini meliputi :

1) Observasi yaitu melakukan pengamatan langsung pada dokumendokumen yang berhubungan dengan variabel penelitian.

2) Wawancara, melakukan wawancara langsung dengan pejabat dan staf di badan pengelolaan keuangan yang berhubungan dengan masalah-masalah dan tujuan penelitian.

\section{Metode Analisis Data}

Penelitian ini adalah merupakan penelitian diskriptif kuantitatif, yaitu untuk mengetahui tingkat efektifitas penggunaan anggaran dengan uraian sebagai berikut:

\section{Analisis Efektifitas}

Nilai efektifitas diperoleh dari perbandingan sebagaimana tersebut diatas diukur berdasarkan keputusan peraturan pemerintah (Decreto Governo) No. 13, tahun 2009, mengatakan kriteria tingkat efektifitas anggaran Belanja tentang Pedoman Penilaian dan Kinerja Keuangan maka kriteria efektifitas realisasi anggaran pemerintah.

\section{PEMBAHASAN Analisis Efektifitas \\ Analisis efektifitas alokasi Anggaran belanja tahun 2010-2014}

Analisa efektifitas adalah ukuran berhasil tidaknya mencapai tujuan suatu organisasi.

Tabel 1 menunjukkan bahwa kinerja Direção Nasional de Aprovisionamento, Logística dan Materiais rata-rata 88,94\% yang berati cukup efektif, hasil ini dapat dikatakan sangat cukup baik. Hal ini ditunjukkan dengan target anggaran alokasikan dari tahun 2010 sampai dengan tahun 2014 mencapai ratarata $88,94 \%$ cukup efektif. Persentase paling rendah terdapat pada tahun 2010 yaitu $81 \%$ cukup efektif.

\section{Analisis Efektifitas Gaji dan Tunjangan}

Hasil analisis terhadap efektifitas anggaran gaji dan tunjangan maka diperoleh perhitungan pada Tabel 2.

Tabel 2 menunjukkan bahwa efektifitas anggaran gaji dan tunjangan rata-rata sebesar 93\% yang berarti efektif. Efektif disini dimaksudkan bahwa realisasi anggaran efektif mendekati pada tingkat efektif $100 \%$. Jumlah realisasi gaji dan tunjangan beberapa tiap tahun anggaran mencapai target pada anggaran yang ditetapkan. Pada tahun anggaran 2010 dari anggaran gaji dan tunjangan senilai \$ $76,000.00$,- terealisasi i $\$ 76,000.00$,- Tahun anggaran 2011 dari nilai anggaran gaji dan tunjangan senilai $\$ 70,000.00,-$ mencapai realisasi \$70,00.00,- - Tahun anggaran 2013 
Tabel 2

Analisis efektifitas Anggaran Gaji dan Tunjangan Tahun Anggaran 2010-2014

\begin{tabular}{cccccl}
\hline Tahun & $\begin{array}{c}\text { Anggaran } \\
(\mathrm{S})\end{array}$ & $\begin{array}{c}\text { Realisasi } \\
(\$)\end{array}$ & $\begin{array}{c}\text { Selisih } \\
(\$)\end{array}$ & $\%$ & \multicolumn{1}{c}{ Ket. } \\
\hline$(1)$ & $(2)$ & $(3)$ & $(4)$ & $(5)$ & \\
2010 & $76,000.00$ & $76,000.00$ & 0 & 100 & Efektif \\
2011 & $70,000.00$ & $70,000.00$ & 0 & 100 & Efektif \\
2012 & $53,000.00$ & $36,573.38$ & $16,426.62$ & 69 & Tidak efektif \\
2013 & $55,000.00$ & $55,000.00$ & 0 & 100 & Efektif \\
2014 & $53,000.00$ & $51,055.90$ & $1,944.10$ & 96 & Efektif \\
Rata-rata & $61,400.00$ & $57,725.86$ & \multicolumn{5}{c}{$93 \%$} \\
\hline \multicolumn{5}{c}{ Sumber : Direção Nacional Aprovisionamento, Logistica e Materiais di Ministério do Comér- }
\end{tabular}
cio, Indústria e Ambiente Timor Leste 2010-2014 (Data diolah )

dari anggaran $\$ 55,000.00$,- mencapai realisasi \$ 55,000.00,- dan Tahun anggaran 2014 dari anggaran 53,000.00,- mencapai realisasi \$ 51,055.90,- secara keseluruhan rata-rata realisasi anggaran dapat dikatakan baik dan efektif namun pada Tahun anggaran 2012 dari anggaran \$53,000.00,- mencapai realisasi \$ 36,573.38, Tahun 2012 ini Line item gaji dan tunjangan mengalami penurunan prosentase dikarenakan adanya pengurangan tenaga kerja (Advisor) sehingga realisasi anggaran yang tersedia tidak mencapai target.

\section{Analisis Efektifitas Belanja Rutin}

Tingkat efektifitas pada pos belanja rutin (Good \& Service) diketahui dengan melakukan perbandingan total realisasi belanja Rutin yang dicapai dengan total anggaran Belanja rutin yang ditetapkan sebelumnya. Pada pos belanja rutin ini antara lain : Perjalanan dinas, Pelatihan/Workshops, Pemelihaan kendaraan, Alat Tulis Kantor, Operasi \& supply, Pemeliharaan peralatan \& Gedung, Pengeluaran operasi, Pengeluaran profesi, dan belanja lain-lain. Dalam hal ini dikatakan bahwa pada pos belanja rutin ini mampu memfasilitasi kinerja yang ada para Direção tersebut. Tingkat efektifitas pada pos belanja rutin dapat dilihat pada Tabel 3. Tabel 3 menunjukkan bahwa anggaran belanja ruitn pada periode penelitian ini rata-rata tingkat efektifitasnya adalah cukup efektif yaitu $86 \%$. Tingkat efektifitasnya pencapaian pos belanja rutin rata-rata $86 \%$ berarti bahwa Direksi
Nasional Procurement, Logistik dan Material mencapai realisasi belanja rutin rata-rata sebesar $86 \%$ dari rata-rata anggaran belanja rutin yang di alokasikan.

Tahun anggaran 2010 dari anggaran belanja rutin senilai $\$ 966,880.00$,- diperoleh realisasi senilai $\$ 776,391.11$,- atau sebesar $80 \%$ yang berarti cukup efektif. Tahun 2011 dari anggaran belanja rutin senilai \$ $668,000.00$,- hanya diperoleh realisasi senilai $\$ 472,430.24$,- atau sebesar $71 \%$ yang berarti kurang efektif. Tahun anggaran 2012 dari anggaran belanja rutin senilai $\$ 69,000.00$,diperoleh realisasi sebesar $\$ 68,909.52$,- atau sebesar $100 \%$ yang berarti sangat efektif. Tahun anggaran 2013 dari anggaran belanja rutin senilai \$ 1,009,000.00,- diperoleh realisasi sebesar $\$ 1,013,544.75,-$ atau sebesar $100 \%$ yang berarti sangat efektif. Tahun anggaran 2014 dari anggaran belanja rutin senilai $\$ 390,000.00$,- hanya di peroleh realisasi sebesar \$312,809.81,- atau sebesar $80 \%$ yang berarti cukup efektif.

Tingkat efektifitas terendah dalam 5 (Lima) tahun anggaran penelitian yaitu pada tahun anggaran 2011 yaitu pencapaian realisasinya hanya sebesar \$ 472,430.24,dari anggaran yang ditetapkan senilai \$ $668,000.00$,- atau sebesar $71 \%$ yang berarti kurang efektif. Hal ini dikarenakan terjadi perubahan struktur pada tubuh kementrian itu sendiri yakni dengan pergantian pimpinan kementrian yang semula status Ministério do Turísmo, Comércio e Industria menjadi 
Tabel 3

Analisis efektifitas Anggaran Pos belanja rutin tahun anggaran 2010-2014

\begin{tabular}{|c|c|c|c|c|}
\hline Tahun & Jenis Belanja Rutin & Anggaran (\$) & Realisasi (\$) & Efektifitas \\
\hline \multirow[t]{10}{*}{ TA 2010} & Perjalanan Dinas & $4,000.00$ & $4,000.00$ & 100 \\
\hline & Pelatihan / workshops & $71,880.00$ & $32,344.80$ & 45 \\
\hline & Pemeliharan kendaraan & $56,000.00$ & $41,917.66$ & 74 \\
\hline & Alat Tulis Kantor & $60,000.00$ & $18,525.75$ & 31 \\
\hline & Operasi \& supply & $20,000.00$ & $11,751.60$ & 59 \\
\hline & Pemeliharaan peralatan \& Gedung & $161,000.00$ & $73,851.30$ & 46 \\
\hline & Pengeluaran operasi & $30,000.00$ & $30,000.00$ & 100 \\
\hline & Pengeluaran profesi & $552,000.00$ & $552,000.00$ & 100 \\
\hline & Belanja lain-lain & $12,000.00$ & $12,000.00$ & 100 \\
\hline & Total & $966,880.00$ & 776,391.11 & $80 \%$ \\
\hline \multirow[t]{10}{*}{ TA 2011} & Perjalanan Dinas & $13,000.00$ & $13,000.00$ & 100 \\
\hline & Pelatihan / workshops & $114,000.00$ & $44,314.44$ & 39 \\
\hline & Pemeliharan kendaraan & $70,000.00$ & $70,000.00$ & 100 \\
\hline & Alat Tulis Kantor & $65,000.00$ & $24,344.30$ & 37 \\
\hline & Operasi \& supply & $57,000.00$ & $57,000.00$ & 100 \\
\hline & Pemeliharaan peralatan \& Gedung & $150,000.00$ & $64,771.50$ & 43 \\
\hline & Pengeluaran operasi & $31,000.00$ & $31,000.00$ & 100 \\
\hline & Pengeluaran profesi & $98,000.00$ & $98,000.00$ & 100 \\
\hline & Belanja lain-lain & $70,000.00$ & $70,000.00$ & 100 \\
\hline & Total & $668,000.00$ & $472,430.24$ & $71 \%$ \\
\hline \multirow[t]{10}{*}{ TA 2012} & Perjalanan Dinas & $6,000.00$ & $3,256.00$ & 54 \\
\hline & Pelatihan / workshops & 0.00 & $3,354.00$ & 100 \\
\hline & Pemeliharan kendaraan & 0.00 & $1,780.87$ & 100 \\
\hline & Alat Tulis Kantor & $6,000.00$ & $14,934.50$ & 249 \\
\hline & Operasi \& supply & $4,000.00$ & 121.60 & 3 \\
\hline & Pemeliharaan peralatan \& Gedung & 0.00 & 0.00 & 0 \\
\hline & Pengeluaran operasi & $8,000.00$ & $3,631.80$ & 45 \\
\hline & Pengeluaran profesi & $36,000.00$ & $41,669.00$ & 116 \\
\hline & Belanja lain-lain & $9,000.00$ & 161.75 & 2 \\
\hline & Total & $69,000.00$ & $68,909.52$ & $99 \%$ \\
\hline \multirow[t]{8}{*}{ TA 2013} & Perjalanan Dinas & $15,000.00$ & $15,000.00$ & 100 \\
\hline & Pelatihan / workshops & $11,000.00$ & $11,000.00$ & 100 \\
\hline & Pemeliharan kendaraan & 0.00 & 0.00 & 100 \\
\hline & Alat Tulis Kantor & $10,000.00$ & $10,000.00$ & 100 \\
\hline & Operasi \& supply & $710,000.00$ & $710,000.00$ & 100 \\
\hline & Pemeliharaan peralatan \& Gedung & $100,000.00$ & $104,544.75$ & 105 \\
\hline & Pengeluaran operasi & $62,000.00$ & $62,000.00$ & 100 \\
\hline & Pengeluaran profesi & $77,000.00$ & $77,000.00$ & 100 \\
\hline
\end{tabular}




\begin{tabular}{llccc}
\hline Belanja lain-lain & $24,000.00$ & $24,000.00$ & 0 \\
& Total & $\mathbf{1 , 0 0 9 , 0 0 0 . 0 0}$ & $\mathbf{1 , 0 1 3 , 5 4 4 . 7 5}$ & $\mathbf{1 0 0 \%}$ \\
TA 2014 & Perjalanan Dinas & $5,000.00$ & $5,000.00$ & 100 \\
Pelatihan / workshops & $11,000.00$ & $6,824.02$ & 62 \\
Pemeliharan kendaraan & 0.00 & 0.00 & 0 \\
Alat Tulis Kantor & $10,000.00$ & $19,363.00$ & 194 \\
Operasi \& supply & $12,000.00$ & $11,712.00$ & 97.6 \\
Pemeliharaan peralatan \& Gedung & $265,000.00$ & $169,670.89$ & 64 \\
Pengeluaran operasi & $25,000.00$ & $11,379.90$ & 45 \\
Pengeluaran profesi & $50,000.00$ & $80,910.00$ & 162 \\
Belanja lain-lain & $12,000.00$ & $7,950.00$ & 66 \\
& $\mathbf{3 9 0 , 0 0 0 . 0 0}$ & $\mathbf{3 1 2 , 8 0 9 . 8 1}$ & $\mathbf{8 0 \%}$ \\
& Total & & $\mathbf{8 6} \%$ \\
\hline
\end{tabular}

Sumber : Direção Nacional Aprovisionamento, Logistica e Materiais di Ministério do Comércio, Indústria e Ambiente Timor Leste 2010-2014 (Data diolah)

Ministério do Comércio, Indústria e Ambiente sehingga berimbas pada beberapa program aktivitas line item yang telah direncanakan pada tahun tersebut tidak terealisasi. Sedangkan tingkat efektifitas tertinggi terjadi pada tahun anggaran 2013 senilai \$ $1,009,000.00,-$ diperoleh realisasi sebesar $\$$ $1,013,544.75$,- atau sebesar $100 \%$ yang berarti sangat efektif. Hal ini disebabkan karena perubahan kontelasi politik yaitu dengan implementasinya program pemerintahan Plano Estrategico Desenvolvimento Nasional (PEDN), maka setiap kementrian di RDTL ini anggaran tahun 2013 yang di alokasikan mengalami kenaikan signifikansi. Dan kemetrian MCIA mendapat dana tambahan pada tahun 2013 untuk menutupi dan melunasi sisa hutang-hutang yang ada.

\section{Analisis Efektifitas Belanja Modal}

Tingkat efektifitas pada pos belanja modal (Minor Capital) diketahui dengan melakukan perbandingan total realisasi belanja modal yang dicapai dengan total anggaran Belanja modal yang ditetapkan sebelumnya. Pada pos belanja modal ini diantaranya Belanja kendaraan, Belanja informatik, Belanja sarana telekomunikasi, Pengeluaran yang tak termasuk bagian lain, Belanja mobiliari \& Acessoris, Belanja peralatan kantor, Belanja perlengkapan air. Dalam hal ini dikatakan bahwa pada pos belanja modal ini mampu memfasilitasi sarana dan prasarana untuk kinerja yang ada. Untuk mengetahui tingkat efektifitas pada pos belanja modal ini maka dapat dilihat dalam Tabel 5.4 berikut ini:

Berdasarkan Tabel 4 dikatakan bahwa pada tahun 2010 realisasi anggaran belanja modal tidak mencapai target yang di tetapkan. Dimana pada tahun 2010 dianggarkan senilai \$ 70,000.00,- hanya terealisasi senilai \$ $53,390.00$ atau sebesar $76 \%$. Hal ini dikarenaka bahwa pada line item Belanja Mobiliari dan Acessoris alokasi anggara sebesar \$ 16.000 tidak dilaksanakan oleh karena adanya bantuan dari Badan Perserikatan BangsaBangsa UNMIT berupa sarana Mobiliari dan acessoris utnuk Kementrian MCIA sehingga anggaran yang tersedia tidak terrealisasi dan anggaran tersebut kembali ke khas Negara Timor Leste. Tahun 2011 dari anggaran belanja modal senilai \$335,000.00,- hanya diperoleh realisasi senilai \$334,664.00,- atau sebesar $100 \%$ yang berarti efektif. Tahun anggaran 2012 dari anggaran belanja modal senilai \$ $363,000.00$,- diperoleh realisasi sebesar $\$$ $351,110.15$,- atau sebesar $97 \%$ yang berarti efektif. Tahun anggaran 2013 dari anggaran belanja modal senilai $\$ 29,000.00$,- diperoleh realisasi sebesar \$29,000.00,- atau sebesar $100 \%$ yang berarti efektif. Tahun anggaran 2014 dari anggaran belanja modal senilai \$ 
Tabel 5

Analisis efektifitas Anggaran Pos Belanja Modal Tahun 2010-2014

\begin{tabular}{|c|c|c|c|c|}
\hline Tahun & Jenis Belanja Modal & Anggaran (\$) & Realisasi (\$) & Efektifitas \\
\hline & (1) & (2) & (3) & $(4)=(3):(2)$ \\
\hline \multirow[t]{8}{*}{ TA 2010} & Belanja kendaraan & $39,000.00$ & $38,425.00$ & $99 \%$ \\
\hline & Belanja informatik & $15,000.00$ & $14,965.00$ & $100 \%$ \\
\hline & Belanja sarana telekomunikasi & 0.00 & 0.00 & $0 \%$ \\
\hline & $\begin{array}{l}\text { Pengeluaran yang tak termasuk } \\
\text { bagian lain }\end{array}$ & 0.00 & 0.00 & $0 \%$ \\
\hline & Belanja mobiliari \& Acessoris & $16,000.00$ & 0.00 & $0 \%$ \\
\hline & Belanja peralatan kantor & 0.00 & 0.00 & $0 \%$ \\
\hline & Belanja perlengkapan air & 0.00 & 0.00 & $0 \%$ \\
\hline & Total & $70,000.00$ & $53,390.00$ & $76 \%$ \\
\hline \multirow[t]{8}{*}{ TA 2011} & Belanja kendaraan & $326,000.00$ & $325,829.00$ & $100 \%$ \\
\hline & Belanja informatik & $7,000.00$ & $6,990.00$ & $100 \%$ \\
\hline & Belanja sarana telekomunikasi & 0.00 & 0.00 & $0 \%$ \\
\hline & $\begin{array}{l}\text { Pengeluaran yang tak termasuk } \\
\text { bagian lain }\end{array}$ & $2,000.00$ & $1,845.00$ & $92 \%$ \\
\hline & Belanja mobiliari \& Acessoris & 0.00 & 0.00 & $0 \%$ \\
\hline & Belanja peralatan kantor & 0.00 & 0.00 & $0 \%$ \\
\hline & Belanja perlengkapan air & 0.00 & 0.00 & $0 \%$ \\
\hline & Total & $335,000.00$ & $334,664.00$ & $100 \%$ \\
\hline \multirow[t]{8}{*}{ TA 2012} & Belanja kendaraan & $192,000.00$ & $183,650.00$ & $96 \%$ \\
\hline & Belanja informatik & $77,000.00$ & $81,662.00$ & $106 \%$ \\
\hline & Belanja sarana telekomunikasi & $2,000.00$ & $1,998.15$ & $100 \%$ \\
\hline & $\begin{array}{l}\text { Pengeluaran yang tak termasuk } \\
\text { bagian lain }\end{array}$ & 0.00 & $6,500.00$ & $0 \%$ \\
\hline & Belanja mobiliari \& Acessoris & $82,000.00$ & $74,820.00$ & $91 \%$ \\
\hline & Belanja peralatan kantor & $10,000.00$ & $2,700.00$ & $27 \%$ \\
\hline & Belanja perlengkapan air & 0.00 & 0.00 & $0 \%$ \\
\hline & Total & $363,000.00$ & $351,110.15$ & $97 \%$ \\
\hline \multirow[t]{8}{*}{ TA 2013} & Belanja kendaraan & $29,000.00$ & $29,000.00$ & $100 \%$ \\
\hline & Belanja informatik & 0.00 & 0.00 & $0 \%$ \\
\hline & Belanja sarana telekomunikasi & 0.00 & 0.00 & $0 \%$ \\
\hline & $\begin{array}{l}\text { Pengeluaran yang tak termasuk } \\
\text { bagian lain }\end{array}$ & 0.00 & 0.00 & $0 \%$ \\
\hline & Belanja mobiliari \& Acessoris & 0.00 & 0.00 & $0 \%$ \\
\hline & Belanja peralatan kantor & 0.00 & 0.00 & $0 \%$ \\
\hline & Belanja perlengkapan air & 0.00 & 0.00 & $0 \%$ \\
\hline & Total & $29,000.00$ & $29,000.00$ & $100 \%$ \\
\hline \multirow[t]{2}{*}{ TA 2014} & Belanja kendaraan & $191,000.00$ & $213,500.00$ & $112 \%$ \\
\hline & Belanja informatik & $96,000.00$ & $96,000.00$ & $100 \%$ \\
\hline
\end{tabular}




\begin{tabular}{lccc} 
Belanja sarana telekomunikasi & $2,965.00$ & $2,000.00$ & $67 \%$ \\
$\begin{array}{l}\text { Pengeluaran yang tak termasuk } \\
\text { bagian lain }\end{array}$ & $4,000.00$ & $4,000.00$ & $100 \%$ \\
$\begin{array}{l}\text { Belanja mobiliari \& Acessoris } \\
\text { Belanja peralatan kantor }\end{array}$ & $60,000.00$ & $10,615.00$ & $18 \%$ \\
Belanja perlengkapan air & $200,035.00$ & $191,535.00$ & $96 \%$ \\
& $3,000.00$ & $3,000.00$ & $100 \%$ \\
\multicolumn{4}{c}{ Total } \\
Rata-rata Belanja Modal
\end{tabular}

Sumber : Direção Nacional Aprovisionamento, Logistica e Materiais di Ministério do Comércio, Indústria e Ambiente Timor Leste 2010-2014 (Data diolah)

$557,000.00$,- hanya di peroleh realisasi sebesar $\$ 520,650.71$,- atau sebesar $93 \%$ yang berarti efektif.

Berdasarkan hasil analisis, cederung bahwa periode penelitian, rata-rata tingkat efektifitasnya adalah efektif yaitu sebesar 93\%. Rata-rata perolehan belanja modal ini relatif baik atau efektif berkisar pada tingkat efektif walaupun tetap berfluktuasi. Tingkat efektifitasnya pencapaian pos belanja modal rata-rata sebesar $93 \%$ berarti bahwa Direção Nacional de Aprovisionamento, Logistica e Materiais mampu mencapai realisasi belanja modal rata-rata sebesar $93 \%$ dari rata-rata anggaran belanja modal yang di alokasikan. Perlu di jelaskan bahwa pada tahun anggaran 2013 Kemetrian mengalokasikan dana sebesar \$ 29,000.00,- dikhususkan untuk pembelian kendaraan yang cenderung kecil oleh karena mengalami perubahan situasi dimana Organisasi PBB mengakhiri masa tugasnyanya di Negara Timor Leste oleh karena itu aset-aset PBB seperti kendaraan dan alat-alat lainnya di handover ke Pemerintah Timor Leste.

\section{Implikasi Penelitian \\ Implikasi Teoritis}

Berdasarkan hasil pembahasan yang dijelaskan dalam diatas maka terdapat dua implikasi teoritis, yaitu : Variabel efektifitas anggaran pada Direção Nacional Aprovisionamento, Logistica e Materiais di Ministério do Comércio, Indústria e Ambiente Timor Leste dengan analisis rasio efektifitas.

\section{Implikasi Praktis}

Berdasarkan hasil penelitian tentang efektifitas dengan mengunakan teknik analisis data rasio efektifitas diharapkan dapat dipakai oleh
Direção Nasional lainnya di dalam Ministério do Comércio, Indústria e Ambiente Timor Leste sebagai acuan referensi atau informasi dalam kebijakan untuk melakukan penyusunan dan merealisasikan anggaran yang di alokasikan tersebut.

\section{SIMPULAN DAN SARAN}

Berdasarkan hasil penelitian, maka dapat disimpulkan : Kinerja pada Direção Nacional Aprovisionamento, Logística e Materiais adalah sangat baik walaupun tidak ada yang mampu melampaui dari yang telah dianggarkan. Hal ini ditunjukkan dengan target anggaran dari tahun 2010 sampai dengan tahun 2014 mencapai rata-rata 88,94\% cukup efektif. Persentase paling rendah terdapat pada tahun 2010 yaitu sebesar $81 \%$. Efektifitas anggaran gaji dan tunjangan ratarata sebesar $134,67 \%$ yang berarti sangat efektif. Sangat efektif disini dimaksudkan bahwa pencapaian realisasi anggaran sangat efektif dengan tingkat efektif di atas 100\%. Efektifitas Anggaran belanja rutin pada periode penelitian ini rata-rata tingkat efektifitasnya adalah cukup efektif yaitu sebesar $86 \%$. Tingkat efektifitasnya pencapaian pos belanja rutin rata-rata sebesar $86 \%$ berarti bahwa Direção Nacional de Aprovisionamento, Logística e Materiais mencapai realisasi belanja rutin rata-rata sebesar $86 \%$ dari ratarata anggaran belanja rutin yang di alokasikan. Efektifitas anggaran tahun 2010 realisasi anggaran belanja modal tidak mencapai target yang di tetapkan. Dimana pada tahun 2010 realisasi anggaran sebesar 76\%. Tahun 2011 dari anggaran belanja modal sebesar 100\% yang berarti efektif. Tahun anggaran 2012 
dari anggaran belanja modal sebesar 97\% yang berarti efektif. Tahun anggaran 2013 dari anggaran belanja modal sebesar 100\% yang berarti efektif. Tahun anggaran 2014 dari anggaran belanja modal sebesar $93 \%$ yang berarti efektif.

Berdasarkan penelitian ini, mencoba memberikan saran sebagai berikut: Dilihat dari hasil realisasi anggaran oleh Direção Nacional de Aprovisionamento, Logística e Materiais maka Ministério do Comércio, Indústria e Ambiente agar tetap mempertahankan dan meningkatkan efektifitas anggaran yang dianggarkan. Kementrian Perdagangan, Perindustrian dan Lingkungan Hidup agar dalam mengalokasikan dana pada setiap pos belanja baik itu belanja rutin maupun belanja modal berdasarkan kinerja masing-masing unit kerja dengan harapan bahwa terpenuhinya aspek efektifitas dan penghematan anggaran. Dalam hal ini untuk belanja rutin kementrian MCIA hendaknya mempertahankan kebutuhan dan kegiatan pada direksi sehingga pengeluaran itu benar-benar sesuai dengan kebutuhan direksi itu sendiri. Agar Kementrian MCIA mengutamakan anggaran yang berbasis anggaran kinerja (Performance Budget)dan dilaksanannya penerapan standar analisis belanja dimasa mendatang. Dalam rangka peningkatan pengelolaan keuangan Direção Direção Nacional de Aprovisionamento, Logística e Materiais hendaknya serta Inspektorat internal Auditing kementrian lebih diberdayakan dalam arti Inspektorat Auditing internal harus benar-benar melakkan fungsi pengawasan sejak tahap perencanaan, pelaksanaan dan pelaporan anggaran (Report Budget), sebab perhitungan Anggaran Negara ini mencermin akuntabilitas Ministério do Comércio, Indústria e Ambiente secara khusus pada Direção Nacional de Aprovisionamento, Logísticae Materiais didalam pengelolaan anggaran Negara sesuai target yang harapan, dengan ini dapat dijadikan sebagai tolak ukuran agar kedepannya bisa lebih berbasis asas efektifitas.

\section{REFERENSI}

Araújo, Miguel, 2014. "Analisis Efektifitas
Dan Efisiensi Terhadap Kebijakan Keuangan Daerah Bagi Pemerintah Daerah Distric Dili." Tesis S-2, Program Pascasarjana Universitas Udayana, Denpasar (Tidak Dipublikasikan)

Bastian, I., 2001, Akuntansi Sektor Publik do Indonesia, Yogyakarta, PPA FE UGM

Dwiyanto, Agus, dkk. 2002. Reformasi Birokrasi Publik di Indonesia. Penerbit PSKK-UGM, Yogyakarta

Devas, N-, Both, A-, Binder, B., Davey, K., dan Keelly, R.. 1989, Keuangan Pemerintah Daerah di Indonesia, Jakarta, UI Press

Goode, Richard. (1984). Government Finance in Developing Countries, the Brooking Institution

Hani Handoko, 2008, Manajemen Personalia dan Sumber Daya Manusia, Cetakan Keenam Belas, Penerbit BPFE Yogyakarta

Halim, A., 2001, Manajemen Keuangan Daerah, Yogyakarta, UPN-YPKN

Jones, roman, and Pendlebury, M., Public Sector Accunting, London, Prentice Hall

Kuncoro, M., 2003, Metode Riset Untuk Bisnis \& Ekonomi, Jakarta, Penerbit Erlangga

Kadmasasmita, A.D. 2009. Akuntabilitas Keuangan Negara: Konsep Dan Aplikasi. Jakarta : STIA LAN

Kuncoro, Mudrajad. 2009. Metode Riset untuk Bisnis \& Ekonomi. Edisi 3. Erlangga. Jakarta.

Inpes nomor 7 Tahun 1999 tentang Akuntabilitas Kinerja Instansi 
Pemerintah. Jakarta: Lembaga Administrasi Negara RI.

Decreto Lei Governo Timor Leste (Nomor 01/2013 De 23 De Janeiro) Peraturan Pemerintah Tentang: Diberikan Wewenang Dan Tanggungjawab Menjalankan Dan Mengimplementasikan Anggaran.

Decreto Lei Governo Timor Leste (LeiOrganica-MCIANo.01/2013 De23

De Janeiro Artigo 11) Nomor 01/2013 Tanggal 23 Januari Pasal 11 Tentang Uraian Tugas Lembaga Teknis Direção Nacional De Aprovisionamento, Logística E Materiais Dengan Kedudukan, Tugas Dan Fungsinya.

Konstitusi Republik Demorkratik Timor Leste Pasal 115 Ayat 1(d) "Pemerintah Memiliki Kewenangan Untuk Menyusun Rencana Dan Anggaran Negara Serta Menjalankannya Dengan Persetujuan Parlemento Nasional".

Konstitusi Republik Demorkratik Timor Leste Pasal 96 "Parlemento Nacional Memiliki Kewenangan Tunggal Untuk Membuat Undang-Undang Mengenai Kebijakan Perpajakan, Dan System Anggaran.

Leonard E. Read, President, 2003 The Freeman "A Monthly Journal of Ideas on Liberty". Fundation for Economic Education. USA.

Lembaga Administrasi Negara Republik Indonesia, 1999, Pedoman Penyusunan Pelaporan Akuntabilitas Kinerja Instansi Pemerintah, Jakarta
Survai Usulan Penelitian dan Laporan Penelitian, Edisi Ketiga. Yogyakarta, Badan Penerbit Fakultas Geografi (BPFG-) UGM

Mardiasmo. 2006. Perwujudan Transparansi Dan Akuntabilitas Publik Melalui Akuntabilitas Sektor Publik: Suatu Sarana Good governance. Jurnal Akuntabilitas Pemerintah. Vol. 2, No. 1 Mei 2006, hal 1-17.

Makmur, Syarif 2008. Pemberdayaan Sumber Daya Manusia Dan Efektifitas Organisasi. Jakarta: PT.Raja Grafindo Persada

Mahmudi.(2010). Analisis Laporan Keuangan Pemerintah Daerah. Penerbit UPP STIM YKPN, Yogyakarta

Moleong, Lexi J.(1994). Metodelogi Penelitian Kualitatif, Bandung PT. Remaja Rosdakarya

Miles \& Hubermas. (1992). Analisis Data Kualitatif: Buku Sumber Tentang Metode Metode Baru. Jakarta: UI Press

Osborne, D, dan Gaebler, T., 1991 Kewirausahakan Birokrasi: Reinventing Government, Diterjemahkan oleh Abdul Rosyid, 1992, PPM, Jakarta

Prawirosentono, 1999-2001, Peraturan Pemerintah Republik Indonesia Nomor 1052002 Tentang Pengelolaan dan Pertanggungjawaban Keuangan Daerah.

Steers M, Richard, 1985. Efektifitas Organisasi. Jakarta: Erlangga

Mahmudi. 2011. Akuntansi Sektor Publik. Schick, Allen. (1998). A Contemporary UII Press. Yogyakarta.

Mantra,I.B., 2001 Langkah-langkah Penelitian Approach to Publik Expenditure Management, Economic Development Institute, The Word Bank. 
Siagian, Sondang P. 2000. Teori Pengembangan Organisasi. Penerbit Bumi Aksara, Jakarta

Syamsi, Ibnu (1994) Dasar-Dasar Kebijaksanaan Keuangan Negara, PT Aneka Cipta, Jakarta

Sabeni, A dan Ghozali, I, 1995, Pokok-Pokok Akuntansi Pemerintah, Edisi, BPFE Yogyakarta

Sunandar, 2011 (Dosen Progrom Studi Akuntansi Politeknik Harapam Bersama) "Analisis Efektifitas dan Efisiensi Pengelolaan Anggaran Pendapatan dan Belanja pada Unit Pengelolaan Keuangan-Badan Keswadayaan Masyarakat (UPK-
BKM) Mandiri Sejahtera Kelurahan Panggung Kota Tegal”. Jurnal Yogyakarta- Jawa Tengah.

Sugiarto, Ni Made, 2004 “Analisis Efektifitas dan Efisiensi Perhitungan Anggaran Pendapatan Belanja Daerah di Kabupaten Badung" Tesis S-2, Program Pascasarjana Universitas Udayana, Denpasar (Tidak dipublikasikan)

Wirasa, T, 2003, "Analisis Perhitungan Anggaran Pendapatan dan Belanja Daerah Propinsi Bali" Tesis S-2, Program Pascasarjana Universitas Udayana, Denpasar (Tidak dipublikasikan) 